\title{
Fenomena Disruptive Innovation: Eksistensi Angkutan Kota Pete-Pete Ditengah Gempuran Moda Transportasi Online Kota Makassar
}

\section{(Disruptive Innovation Phenomenon: The Existence of Pete-Pete City Transportation Amidst the onslaught of Online Transportation Modes in Makassar City)}

\section{Muhammad Ihsan',}

${ }^{1}$ Email: iccankihsanmuhammad@gmail.com

\section{A R T I C L E I N F O}

\section{How to Cite:}

Ihsan, M. (2021). Fenomena

Disruptive Innovation:

Eksistensi Angkutan Kota

Pete-Pete Ditengah Gempuran

Moda Transportasi Online

Kota Makassar. Hasanuddin

Journal of Sociology (HJS),

3(1), 1-16.

\section{Keywords:}

Pete-pete, Modes of Online

Transportation, Innovation,

Rationality

\section{Kata Kunci :}

Pete-pete, Moda Transportasi

Online, Inovasi, Rasionalitas

\begin{abstract}
A B S T R A C T
This study aims to determine how the existence of pete-pete city transportation and the survival strategy of pete-pete drivers in the midst of the onslaught of online transportation modes. The method used in this research is qualitative with a phenomenological approach. The results showed the existence of pete-pete was now at a critical threshold. The shift of passengers to online modes of transportation makes the number of pete-pete decreases significantly each year. The survival strategy adopted by pete-pete drivers also cannot be maximized due to certain conditions, in general the drivers also only rely on income from attracting pete-pete. The logic of people who want a mode of transportation that is not only easy and inexpensive, but also practical and accessible whenever and wherever shows that society is more rational now. Rationality is inevitable in modern society and a spirit of modernity. Pete-pete is inferior to the innovations offered by online transportation modes. Pete-pete is inferior to current growth desires and logic. The online mode of transportation as a disruptive innovation that not only replaces old physical technology with digital technology, but also produces something completely new and more efficient. Its nature is not only destructive but also creative.
\end{abstract}

\begin{abstract}
ABSTRAK
Penelitian ini bertujuan untuk mengetahui bagaimana eksistensi angkutan kota pete-pete dan strategi bertahan hidup sopir pete-pete di tengah gempuran moda transportasi online. Metode yang digunakan dalam penelitian ini adalah kualitatif dengan pendekatan fenomenologi. Hasil penelitian menunjukkan eksistensi pete-pete saat ini berada di batas ambang kritis. Beralihnya penumpang ke moda transportasi online membuat jumlah pete-pete menurun signifikan tiap tahunnya. Strategi bertahan hidup yang ditempuh oleh para sopir pete-pete juga
\end{abstract}

* Corresponding author. Telp.: -

E-mail address: iccankihsanmuhammad@gmail.com 
tidak bisa dimaksimalkan akibat beberapa kondisi tertentu, umumnya para sopir juga hanya mengandalkan penghasilan dari narik pete-pete. Logika masyarakat yang menginginkan sebuah moda transportasi yang tidak hanya mudah dan murah, namun juga praktis dan bisa diakses kapan dan dimanapun menunjukkan masyarakat semakin rasional saat ini. Rasionalitas menjadi sesuatu yang tidak terelakkan dalam masyarakat modern dan menjadi roh bagi modernitas. Pete-pete kalah dengan inovasi yang ditawarkan oleh moda trasnportasi online. Petepete kalah dengan hasrat dan logika pertumbuhan saat ini. Moda transportasi online sebagai sebuah disruptive innovation yang tidak hanya menggantikan teknologi lama yang serba fisik dengan teknologi digital, namun juga menghasilkan sesuatu yang benar-benar baru dan lebih efisien. Sifatnya tidak hanya destruktif namun juga kreatif.

\section{PENDAHULUAN}

“Daeng, kiri daeng” ungkapan yang mungkin familiar di telinga kita terlebih bila kita adalah salah satu pengguna angkutan kota di Makassar yang cukup populer yakni Angkutan Kota Pete-Pete. Siapa pun yang pernah ke Makassar akan mengenal Pete-pete, entah ia pernah menaikinya atau sekedar melihatnya menepi untuk menaikkan atau menurunkan penumpang. Menariknya, Pete-pete ini tidak hanya terlihat namun juga terdengar sebab moda transportasi publik warga kota makassar ini biasanya dilengkapi dengan sound system yang mengeluarkan musik dalam volume yang nyaring bak pameran otomotif. Asri (2015: 89) jika taksi adalah semacam moda angkutan darat yang diperuntukkan bagi individu-individu porselen yang jarang berkeringat, maka Pete-pete adalah wahana transportasi publik dalam pengertian kepublikan sebagai rujukan demografis yang menampung banyak manusia dengan latar belakang yang beragam.

Kasali (2017: viii) melihat bahwa kini dunia tengah menyaksikan perpindahan dari mobil bertenaga bensin ke self-driving car yang dikendalikan teknologi informasi (internet) melalui smartphone. Petugas bengkel kelak bukan lagi seorang montir yang dikenal pada abad ke-20, melainkan para ahli IT yang bekerja dengan perangkat lunak. Suka tidak suka, Internet of Things membentuk kita mulai hari ini.

Tahun 2015 merupakan masa yang fenomenal bagi perkembangan layanan transportasi on demand, atau yang biasa dikenal dengan transportasi online. Dalam rentang waktu dua belas bulan, GO-JEK berkembang dari sebuah aplikasi mobile baru menjadi sebuah layanan besar, yang kemudian mendapat perlawanan dari GrabTaxi dengan layanan GrabBike. Persaingan tersebut pun semakin sengit dengan masuknya layanan asal Amerika Serikat, Uber, yang hadir di tanah air sejak tahun 2014.

Bisnis transportasi darat mengalami penurunan drastis pada sepanjang 2016. Ketua Organisasi Angkutan Darat (Organda) DKI Jakarta, Shafruhan Sinungan, menagatakan, penurunan omzet terutama 
terjadi pada moda transportrasi seperti taksi, bajaj (angkutan lingkungan), dan mikrolet. Taksi bahkan mengalami penuruinan omzet hingga 50\% pada tahun ini. Bisnis transportasi darat pada 2016 secara umum ambruk 60\%, khususnya untuk beberapa sektor seperti taksi, angling (angkutan lingkungan), dan mikrolet. Taksi turun 40-50\%, mikrolet 30\% (Kasali 2017: 85).

Di awal tahun 2016, di tanah air ribuan pengemudi angkutan umum yang merasa pendapatan mereka menurun akibat kehadiran layanan transportasi online akhirnya melakukan demonstrasi. Massa yang didominasi oleh pengemudi taksi tersebut menuntut layanan Uber dan Grab agar segera ditutup. Insiden ini tak hanya berlangsung sekali mereka pun kembali melakukan aksi demonstrasi seminggu setelahnya. Tercatat beberapa bentrokan cukup besar antara pengemudi angkutan kota dengan pengemudi transportasi online. Seperti yang termuat dalam portal media online Kumparan.com edisi 10 maret 2017 melampirkan beberapa bentrokan cukup besar seperti di Depok, 3 Oktober 2015 bentrokan antara ojek online dan ojek pangkalan depan kampus Universitas Indonesia. Lalu di Jakarta 22 maret 2016, Sopir Taxi dan Sopir Angkot mogok jalan dan melakukan aksi demo, sweeping dilakukan dengan kekerasan ke Sopir Ojek online beratribut bahkan penumpang ikut jadi korban pemukulan. Yogyakarta 26 Februari 2017, sebuah mobil milik pengendara aplikasi Go-Car dirusak oleh beberapa Sopir taksiDan beberapa kasus bentrokan berulang lainnya seperti di Denpasar, Medan, Tangerang, Bandung.

Di awal tahun 2016, di tanah air ribuan pengemudi angkutan umum yang merasa pendapatan mereka menurun akibat kehadiran layanan transportasi online akhirnya melakukan demonstrasi. Massa yang didominasi oleh pengemudi taksi tersebut menuntut layanan Uber dan Grab agar segera ditutup. Insiden ini tak hanya berlangsung sekali mereka pun kembali melakukan aksi demonstrasi seminggu setelahnya. Di Makassar sendiri, beberapa berita yang dihimpun terkait dinamika transportasi konvensional vs transportasi online. Seperti yang diberitakan portal online Rakyatku.com edisi 28 September 2017 momen sopir pete-pete dan tukang bentor turun kejalan memprotes dan merazia terkait kehadiran transportasi online. Mereka melakukan aksi dan konvoi di sejumlah titik kota seperti di Jalan AP Pettarani dan Pelita Raya yang selanjutnya titik temu di Fly Over. Menurut salah satu sopir petepete, Dg Jarre, aksi tersebut tak lepas dari pendapatannya yang menurun drastis sejak keberadaan angkutan berbasis online, orang-orang sudah enggan lagi naik pete-pete atau bentor.

Edy Suandi Hamid pada jurnalnya Distruptive Innovation: Manfaat Dan Kekurangan Dalam Konteks Pembangunan Ekonomi (2018: 1) Berbagai fenomena yang ada tersebut sudah jelas terjadi bukan tanpa sebab. Pertama, perkembangan teknologi memiliki pengaruh yang sangat besar terhadap arah perubahan dan inovasi. Kedua, kebutuhan yang tinggi akan efisiensi dan efektifitas menyebabkan produsen perlu melakukan inovasi yang memadai. Pada tataran ini dapat dikatakan bahwa pepatah 
mengatakan "tidak ada asap jika tidak ada api” berlaku dalam konteks munculnya pelaku baru dengan berbagai inovasi. Kebutuhan akan efisiensi merupakan sebab yang kuat bagaimana produsen harus melakukan inovasi untuk masuk ke dalam pasar. Distruptive Innovation yang dimaksud adalah perkembangan teknologi yang mengganggu dalam konteks bahwa munculnya inovasi teknologi baru yang mengganggu keberadaan teknologi lama.

Penelitian ini bertujuan untuk mengetahui bagaimana eksistensi pete-pete dan strategi bertahan hidup yang ditempuh sopir pete-pete ditengah gempuran moda transportasi online kota Makassar

\section{METODE PENELITIAN}

Penelitian ini menggunakan metode kualitatif. Sebagaimana yang dijelaskan oleh Denzin dan Lincoln dalam Agus Salim (2006), dimana penelitian kualitatif berupaya memahami dan memberi tafsiran pada fenomena yang dilihat dari makna yang diberikan orang-orang kepada fenomena tersebut. Maleong sendiri mendefinisikannya sebagai penelitian yang berusaha memahami sebuah fenomena tentang sesuatu yang dialami oleh subjek penelitian secara holistik, dengan mendeskripsikannya dalam bentuk kata-kata dan bahasa, pada suatu konteks khusus yang alamiah dan memanfaatkan berbagai metode yang alamiah (Maleong, 2016). Jenis pendekatan yang digunakan adalah fenomenologi yang dimana penelitian ini dilakukan dalam situasi yang alami sehingga tidak ada batasan dalam memaknai atau memahami fenomena yang dikaji. Maleong (2016: 14-17) menyatakan bahwa fenomenologi merupakan pandangan berpikir yang menekankan focus kepada pengalaman-pengalaman subjektif manusia dan interpretasi-interpretasi dunia. Peneliti dalam pandangan fenomonelogis berusaha memahami arti peristiwa dan kaitan-kaitannya terhadap orang-orang yang berada dalam situasi-situasi tertentu. Penelitian ini dilakukan di Kota Makassar. lokasi peneltian dipilih secara sengaja (purposive) dengan beberapa pertimbangan. Pertama, nama atau sebutan Pete-pete lahir di Kota Makassar. Kedua, jumlah unit Pete-pete untuk ditingkat Provinsi Sul-Sel terbanyak di Kota Makassar. Ketiga, banyaknya jumlah Pete-pete di Kota Makassar diharapkan bisa menambah varietas informasi yang didapatkan.

Teknik sampling dalam penelitian ini menggunakan purposive sampling, yaitu teknik pengambilan sampel sumber data dengan pertimbangan tertentu (Sugiyono, 2015: 144). Informan dalam penelitian ini dipilih dengan pertimbangan tertentu bahwa sampel data yang diambil merujuk pada orang-orang atau informan yang dianggap dapat memberi informasi yang diharapkan. Seperti Pegawai instansi di lingkungan Dinas Perhubungan Setempat, anggota Organda (Organisasi Angkutan Darat), atau perangkat daerah terkait lainnya. Penelitian ini dilakukan dengan beberapa teknik pengumpulan data diantaranya observasi, wawancara mendalam, dan dokumentasi. Observasi atau pengalaman dilakukan 
terhadap objek atau subjek penelitian, tidak hanya pada awal penelitian namun juga selama penelitian berlangsung. Menurut Poerwandari (1998) Observasi adalah tindakan yang dilakukan mengarah pada pengamatan secara akurat guan menemukan dan mencatat fenomena-fenomena yang dianggap penting, dan mempertimbangkan keterkaitan antar aspek dalam fenomena tersebut. Dalam peneltian ini, Peneliti menyusun pedoman dasar terkait apa saja yang menjadi objek observasi dalam pengumpulan data-data penelitian. Aspek yang di observasi dalam penelitian ini meliputi beberapa hal yaitu Pertama, objek tempat (place). Objek tempat yang dimaksud seperti rute dimana Pete-pete beroperasional, tempat ngetem atau tamplas, tempat pembayaran retribusi, tempat beristirahat. Kedua, objek pelaku (actor). Objek ini mencakup Sopir Pete-pete yang beroperasional di Kota Makassar, Pegawai atau Stekholder Dishub Provinsi dan kota Makassar, Anggota Organda, serta perangkat daerah terkait lainnya. Ketiga, objek aktivitas (activity). Aktivitas yang diobservasi dalam penelitian ini mencakup bagaimana kegiatan operasional yang dilakukan para Sopir pete-pete saat ini dan kondisi yang mereka rasakan sebelum dan setelah munculnya moda Transpotasi Online, bagaimana relasi antar sesama sopir, serta strategi bertahan hidup yang mereka tempuh untuk menjaga keberlangsungan sosial ekonomi mereka. Mulyana \& Dedi Junaedi (2008; 180) mengatakan: bahwa wawancara mendalam merupakan wawancara tidak terstruktur, wawancara kualitatif, wawancara intensif, dan wawancara terbuka (opened interview). Wawancara tidak terstrukur ini bersifat luwes, susunan-susunan pertanyaan dapat diubah pada saat wawancara, disesuaikan dengan kebutuhan-kebutuhan dan kondisi saat wawancara, termasuk karakteristik sosial budaya (agama, suku, gender, usia, tingkat pendidikan, pekerjaan, dan sebagainya). Berdasarkan sasaran penjawabnya, jenis wawancara yang dilakukan dalam penelitian ini adalah wawancara perorangan. Wawancara perorangan menurut Narbuko dan Abu Ahmadi (2007) adalah proses tanya-jawab secara langsung (tatap muka) antara orang yang melakukan wawancara dengan orang yang diwawancarai. Wawancara perseorangan ini dilakukan guna mendapatkan data yang lebih intensif. Wawancaranya berfokus ke bagaimana eksistensi angkutan kota Pete-pete dan strategi bertahan hidup yang ditempuh Sopir pete-pete saat ini ditengah gempuran moda transportasi online saat ini. Pada tahap dokumentasi, menurut Noor (2011), fakta dan data yang dibutuhkan dalam penelitian sebagian besar tersimpan dalam bentuk dokumentasi. Sifat utama dari data dokumentasi tidak terbatas karena itu peneliti memiliki peluang untuk menemukan hal-hal yang pernah terjadi di waktu silam yang mungkin saja dibutuhkan oleh peneliti saat di lapangan. Secara detail, bahan dokumenter terbagi beberapa macam, yaitu autobiografi, surat pribadi, buku atau catatan harian, memorial, klipping, dokumen pemerintah atau swasta, data di server dan flashdisk, dan data yang tersimpan di website (Noor, 2011: 141). 
Tabel 1. Daftar Informan Sopir Pete-Pete

\begin{tabular}{|c|c|c|c|c|}
\hline No & $\begin{array}{c}\text { Inisial } \\
\text { Informan }\end{array}$ & Umur & $\begin{array}{l}\text { Lama Jadi Sopir / } \\
\text { Status Kendaran }\end{array}$ & Rute yang dilalui/trayek \\
\hline 1 & DJ & $\begin{array}{c}42 \\
\text { Tahun }\end{array}$ & $\begin{array}{c}19 \text { tahun / } \\
\text { sewa mobil }\end{array}$ & $\begin{array}{l}\text { Terminal Malengkeri - Cendrawasih - } \\
\text { Kampus Unhas (kode B1) }\end{array}$ \\
\hline 2 & DY & $\begin{array}{c}40 \\
\text { Tahun }\end{array}$ & $\begin{array}{c}22 \text { tahun / } \\
\text { mobil sendiri }\end{array}$ & $\begin{array}{l}\text { Terminal Malengkeri - Cendrawasih - } \\
\text { Kampus Unhas (kode B1) }\end{array}$ \\
\hline 3 & $\mathrm{R}$ & $\begin{array}{c}53 \\
\text { Tahun }\end{array}$ & $\begin{array}{l} \pm 30 \text { tahun / } \\
\text { mobil sendiri }\end{array}$ & $\begin{array}{l}\text { Terminal Malengkeri - Cendrawasih - } \\
\text { Kampus Unhas (kode B1) }\end{array}$ \\
\hline 4 & SDN & $\begin{array}{c}52 \\
\text { Tahun }\end{array}$ & $\begin{array}{c}20 \text { tahun / } \\
\text { mobil sendiri }\end{array}$ & $\begin{array}{l}\text { Pasar butung - Cendrawasih - Terminal } \\
\text { Malengkeri (kode B) }\end{array}$ \\
\hline 5 & RDN & $\begin{array}{c}44 \\
\text { Tahun }\end{array}$ & $\begin{array}{l} \pm 20 \text { tahun / } \\
\text { sewa mobil }\end{array}$ & $\begin{array}{l}\text { Pasar butung - Cendrawasih - Terminal } \\
\text { Malengkeri (kode B) }\end{array}$ \\
\hline 6 & $\mathrm{DN}$ & $\begin{array}{c}48 \\
\text { Tahun }\end{array}$ & $\begin{array}{c}25 \text { tahun / } \\
\text { mobil sendiri }\end{array}$ & $\begin{array}{l}\text { Pasar butung - Cendrawasih - Terminal } \\
\text { Malengkeri (kode B) }\end{array}$ \\
\hline 7 & $\mathrm{AK}$ & $\begin{array}{c}35 \\
\text { Tahun }\end{array}$ & $\begin{array}{c}5 \text { tahun / } \\
\text { sewa mobil }\end{array}$ & Terminal Daya - Maros - Pangkep \\
\hline 8 & MS & $\begin{array}{c}40 \\
\text { Tahun }\end{array}$ & $\begin{array}{l} \pm 10 \text { tahun / } \\
\text { mobil sendiri }\end{array}$ & Terminal Daya - Maros - Pangkep \\
\hline 9 & $\mathrm{MD}$ & $\begin{array}{c}38 \\
\text { Tahun } \\
\end{array}$ & $\begin{array}{l} \pm 20 \text { tahun / } \\
\text { mobil sendiri }\end{array}$ & Terminal Daya - Maros - Pangkep \\
\hline 10 & UD & $\begin{array}{c}52 \\
\text { Tahun }\end{array}$ & $\begin{array}{l} \pm 20 \text { tahun / } \\
\text { sewa mobil }\end{array}$ & Makassar Mall - Veteran - Sungguminasa \\
\hline 11 & DD & $\begin{array}{c}36 \\
\text { Tahun }\end{array}$ & $\begin{array}{c}7 \text { tahun / } \\
\text { mobil sendiri }\end{array}$ & $\begin{array}{l}\text { Term.C Bungaya (Gowa) - Jalan Gunung } \\
\text { Bulusaraung - PP }\end{array}$ \\
\hline 12 & DT & $\begin{array}{c}41 \\
\text { Tahun }\end{array}$ & $\begin{array}{l} \pm 20 \text { tahun / } \\
\text { mobil sendiri }\end{array}$ & $\begin{array}{l}\text { Term.C Bungaya (Gowa) - Jalan Gunung } \\
\text { Bulusaraung - PP }\end{array}$ \\
\hline 13 & DA & $\begin{array}{c}59 \\
\text { Tahun }\end{array}$ & $\begin{array}{l} \pm 40 \text { tahun / } \\
\text { mobil sendiri }\end{array}$ & $\begin{array}{l}\text { Perumnas Panakkukang - UNM - Kampus } \\
\text { Unhas (kode E1) }\end{array}$ \\
\hline 14 & PS & $\begin{array}{c}55 \\
\text { Tahun } \\
\end{array}$ & $\begin{array}{l}25 \text { tahun / } \\
\text { mobil sendiri }\end{array}$ & $\begin{array}{l}\text { Perumnas Panakkukang - UNM - Kampus } \\
\text { Unhas (kode E1) }\end{array}$ \\
\hline 15 & $\mathrm{SF}$ & $\begin{array}{c}49 \\
\text { Tahun }\end{array}$ & $\begin{array}{l} \pm 20 \text { tahun / } \\
\text { mobil sendiri }\end{array}$ & $\begin{array}{l}\text { Perumnas Panakkukang - UNM- Unhas } \\
\text { (kode E1) }\end{array}$ \\
\hline 16 & MR & $\begin{array}{c}48 \\
\text { Tahun }\end{array}$ & $\begin{array}{l}18 \text { tahun / } \\
\text { mobil sendiri }\end{array}$ & $\begin{array}{l}\text { Makassar Mall - Veteran - Term. } \\
\text { Malengkeri (kode F) }\end{array}$ \\
\hline 17 & DR & $\begin{array}{c}55 \\
\text { Tahun } \\
\end{array}$ & $\begin{array}{l} \pm 30 \text { tahun / } \\
\text { mobil sendiri }\end{array}$ & $\begin{array}{l}\text { Makassar Mall - Veteran - Term. } \\
\text { Malengkeri (kode F) }\end{array}$ \\
\hline 18 & $\mathrm{~S}$ & $\begin{array}{c}53 \\
\text { Tahun } \\
\end{array}$ & $\begin{array}{c}23 \text { tahun / } \\
\text { mobil sendiri }\end{array}$ & $\begin{array}{l}\text { Makassar Mall - Pabaengbaeng - Perumnas } \\
\text { Panakkukang (kode J) }\end{array}$ \\
\hline
\end{tabular}

Sumber : Observasi Lapangan Tahun 2019

Data informan dari Pemerintah dan Organisasi terkait :

1. Informan Edisa Ade

Edisa Ade adalah informan dari Dinas Perhubungan Provinsi Sulawesi Selatan yang merupakan Kepala Seksi Angkutan Tidak Dalam Trayek. Peneliti banyak mendapat informasi dari informan terkait dinamika moda transportasi online beberapa tahun terakhir khususnya di kota Makassar yang begitu 
mempengaruhi keberadaan pelaku angkutan konvensional serta regulasi yang mengatur angkutan tersebut. Informan juga menjelaskan tentang kelebihan dan kekurangan dari penyelengaraan moda transportasi online ini. selain itu, dijelaskan juga sejauh mana upaya yang telah dilakukan Dishub Provinsi dan Pemerintah terkait polemik hadirnya moda transporatsi online.

2. Informan Hendro

Hendro adalah informan dari Dinas Perhubungan Kota Makassar. Kebetulan terkait data yang berhubungan transportasi darat di kota Makassar informan yang menangani. Peneliti banyak mendapat informasi dari informan terkait data dan kondisi angkutan pete-pete saat ini. selain itu informan juga banyak bercerita tentang dinamika moda transportasi online beberapa tahun terakhir hingga tingkat nasional, serta sejauh mana upaya yang telah dilakukan ini terkait polemik antar pete-pete dengan moda transporatsi online.

3. Informan Zainal Abidin

Zainal Abidin adalah ketua Organisasi Angkutan Darat (organda) kota Makassar. Seperti yang telah dijelaskan sebelumnya Organda merupakan organisasi independen yang menaungi pete-pete di kota Makassar. peneliti bertemu dengan informan sebanyak dua kali, yang pertama di kantor Dishub Jalan Malengkeri, saat itu informan sedang memberi konsultasi ke beberapa sopir yang ingin mengurus pajak kendaraannya. Kedua kali informan bertemu di kantor Samsat Kota Makassar. Nama informan juga beberapa kali muncul di portal berita online Makassar saat memberikan keterangan dan penjelasan tentang polemik yang dhadapi sopir pete-pete saat ini.

\section{HASIL PENELITIAN DAN PEMBAHASAN}

\subsection{Gambaran Umum Pete-Pete Kota Makassar}

Sesuai Permenhub Nomor 15 tahun 2019, Pete-pete tergolong penyelenggaraan angkutan orang dengan kendaraan bermotor umum dalam trayek. Dengan kata lain, Pete-pete beroperasi sesuai dengan rute yang telah ditentukan sesuai izin trayeknya. Jalur trayek Pete-pete dapat diketahui melalui warna atau kode berupa huruf atau angka yang berada di badannya. Terdapat data 17 rute trayek utama petepete yang didapatkan peneliti dari Dinas Perhubungan Kota Makassar. Setiap rute trayek diberikan kode huruf atau angka tertentu. Untuk pete-pete AKDP (Antar Kota Dalam Provinsi) terdapat 2 jenis yakni Pete-Pete Rute Trayek Terminal Daya - Maros - Pangkep dan Pete-Pete Merah Rute Trayek lintas Makassar - Gowa - Takalar - Jeneponto.

Pada bahan rapat Dinas Perhubungan Kota Makassar tahun 2014, ada perencanaan terkait penambahan 4 rute trayek daerah pinggiran kota Makassar yakni terminal Maelngkeri - Barombong (V), Terminal Regional Daya - BTN Mangga Tiga (L), Terminal Regional Daya - Perumnas Sudiang 
(M), dan Terminal Regional Daya - Perumahan Villa Mutiara (N).

\subsection{Faktor Muatan (Load Factor) Pete-pete Kota Makassar}

Faktor Muatan atau (load factor) merupakan pembagian antara permintaan (demand) yang ada dengan pemasukan (supply) yang tersedia. Faktor muatan dapat menjadi petunjuk untuk mengetahui jumlah armada yang ada masih kurang, mencukupi, atau melebihi kebutuhan suatu lintasan angkutan umum serta dapat dijadikan indikator dalam mewakili efisiensi suatu rute. Load factor angkutan umum disetiap rutenya berkisar mulai 30\% sampai 100\% (Putra, 2017).

Berdasarkan data dari Dinas Perhubungan Kota Makassar, di tahun 2007 keluar Surat Kepututsan (SK) Walikota untuk menutup peremajaan. Asumsinya tahun 2007 tidak ada lagi kendaraan baru, tidak ada lagi penambahan pete-pete. kuotasi atau load factor untuk pete-pete yang bisa melayani kota Makassar sebesar 4113 unit hingga kira-kira tahun 2014. Selanjutnya diadakan kembali load factor di tahun 2017 dengan bekerjasama dengan jasa konsultasi, hasil data permintaan di lapangan atau potensi yang ada melalui pemantauan ngetem pete-pete, hasil data real kebutuhan pada tahun 2017 didapatkan sebesar 2923 unit.

\subsection{Eksistensi Angkutan Kota Pete-Pete di Tengah Gempuran Moda Transportasi Online}

\section{Kota Makassar}

Berdasarkan data dari Dinas Perhubungan Kota Makassar, jumlah kuotasi atau load factor Petepete yang disetujui sesuai SK Walikota di tahun 2007 hingga tahun 2014 sebesar 4113 unit. Kemudian di tahun 2017, diadakan kembali load factor menurun menjadi 2923 unit. Namun dari load factor 2923 unit yang disetujui, diperkirakan hanya sekitar 2500-an unit pete-pete yang beroperasi hingga tahun 2019. Dikonfirmasi oleh Ketua Organda Zainal Abidin, ia menyebutkan bahwa jumlah pete-pete saat ini berkurang drastis dari data yang awalnya 4113 unit, kini diperkirakan hanya berkisar 2500an.

Tabel 2. Jumlah Pete-Pete yang Terhitung Aktif Dari Tahun 2017 - 2019

\begin{tabular}{|c|c|c|c|c|}
\hline \multirow{2}{*}{ No } & \multirow{2}{*}{ Trayek } & \multicolumn{3}{|c|}{ Jumlah Petepete } \\
\cline { 2 - 5 } & & $\mathbf{2 0 1 7}$ & $\mathbf{2 0 1 8}$ & $\mathbf{2 0 1 9}$ \\
\hline 1 & $\mathrm{~A}$ & 95 & 68 & 48 \\
\hline 2 & $\mathrm{~B}$ & 213 & 178 & 132 \\
\hline 3 & $\mathrm{C}$ & 96 & 67 & 75 \\
\hline 4 & $\mathrm{D}$ & 390 & 221 & 259 \\
\hline 5 & $\mathrm{E}$ & 109 & 54 & 30 \\
\hline 6 & $\mathrm{~F}$ & 103 & 83 & 62 \\
\hline 7 & G & 92 & 107 & 107 \\
\hline 8 & H & 114 & 148 & 149 \\
\hline
\end{tabular}




\begin{tabular}{|c|c|c|c|c|}
\hline 9 & I & 119 & 91 & 72 \\
\hline 10 & J & 94 & 46 & 31 \\
\hline 11 & S & 98 & 46 & 61 \\
\hline 12 & W & 20 & 7 & - \\
\hline 13 & B1 & 88 & 48 & 28 \\
\hline 14 & C1 & 4 & - & 17 \\
\hline 15 & E1 & 104 & 41 & 7 \\
\hline 16 & F1 & 45 & 22 & 1078 \\
\hline
\end{tabular}

Sumber :Dinas Perhubungan Kota Makassar Tahun 2019

Bila melihat data diatas, dari perkiraan jumlah pete-pete yang beredar dijalan sebanyak kuurang lebih 2500 unit. jumlah Pete-pete yang aktif registrasi tiap tahunnya seperti izin trayek, KIR, dan lainlain hanya sebesar 1784 unit ditahun 2017, kemudian menurun lagi menjadi 1227 unit ditahun 2018, dan data terakhir yang didapatkan per bulan oktober 2019 sebesar 1078 unit. Banyaknya pete-pete yang tidak melakukan registrasi diakui oleh Hendro yang merupakan staf bagian Transportasi Publik Dinas Perhubungan Kota Makassar.

"Ada yang narik pete-pete sudah tidak tercacat didata dishub tapi masih jalan karena kondisi penghasilannya. Dishub memliki kewenangan untuk menindak atau menarik izin trayek pete-pete yang berkeliaran tapi ilegal, namun Dishub mengutamakan himbauan-himbauan untuk memperpanjang kembali, surat-surat mereka dengan tindakan persuasif. Karena kalau di kerasi pasti akan ada perlawanan". (Wawancara dengan informan Hendro 8 November 2019)

Bila mengacu data yang dikeluarkan oleh Dinas Perhubungan kota Makassar, Pete-pete saat ini berada di batas ambang kritis. Bagaimana tidak bila melihat rasio jumlah pete-pete yang tercatat aktif melakukan pengurusan surat perizinan dalam kurun 2 tahun saja dari 2017 yang berjumlah 1784 unit hingga per oktober 2019 hanya berjumlah 1078, terjadi penurunan signifikan sebanyak 700 unit lebih yang tidak melakukan registrasi. Penurunan jumlah pete-pete ini bila ditelusuri bukan tanpa sebab, bisa dibilang sejak awal kehadiran moda transportasi online di tahun 2015 lalu, satu demi satu penumpang pete-pete mulai mencoba moda online. Banyaknya pelayanan yang membuat penumpang jadi nyaman sehingga banyak penumpang pete-pete mulai beralih. Akibatnya, 3 tahun belakangan ini moda online makin menjamur di kota Makassar.

Peneliti mencoba mengonfirmasi data penurunan jumlah pete-pete yang beroperasi yang dikeluarkan dishub dengan menemui beberapa sopir pete-pete yang masih beroperasi hingga saat ini. Hasilnya memang tak beda jauh menurut mereka, jumlah pete-pete berkurang drastis hingga $50 \%$ empat tahun terakhir ini. Banyak juga pengusaha pete-pete yang sudah bangkrut akibat tidak bisa bersaing dengan moda transporatasi online. Bahkan di rute tertentu diprediksi sisa $30 \%$ pete-pete yang masih aktif. Informan RDN salah satu informan yang telah menjadi sopir pete-pete selama 20 tahun mengaku untuk 
trayek operasionalnya sendiri jumlah pete-petenya sangat berkurang, mungkin sisa $30 \%$ dari jumlah sebelum munculnya moda transportasi online.

"Kalau diliat-liat sisa bagi tiganya mami mobil yang jalan di rute malengkeri - pasar butung. Semenjak itu ada online, penumpang ta disisir yang pinggir jalan. Dulu disini ada yang namanya pete-pete 88, kontraktor punya tinggal di jalan Daeng Tata 3. Unitnya hampir 100, tapi sekarang tinggal 2 unit, tidak bisa mi bersaing dengan online. belum lagi itu pete-pete mungkin kredit, jadi apami mau napake bayar di bank sementara pemasukan loyo" (Wawancara dengan informan SDN tanggal 20 September 2019)

Salah satu informan di rute trayek unhas berinsial $S$ menuturkan akibat dari jumlah pete-pete yang semakin berkurang, harga pete-pete jatuh dipasaran. Beliau sangat menyayangkan kondisi tersebut, padahal diakuinya trayek operasionalnya salah satu rute yang banyak diperebutkan sopir lainnya.

"Sekarang turun sekali harganya mobil pak. Dulu untuk daerah Unhas saja harga izin trayeknya kurang lebih Rp 50 juta, tapi sekarang bermodal Rp 25 juta sudah bisa mi dapat mobil sekaligus izin trayeknya juga. Padahal pete-pete unhas itu terknela sekali dulu karena strategis lokasi trayek" (Wawancara dengan informan S tanggal 26 September 2019).

Sebelum hadirnya moda transportasi online, jam operasional pete-pete bahkan bisa dibilang sampai 24 jam. Pagi, siang, malam, hingga dini hari ada saja pete-pete yang lalu lalang. Dari penuturan beberapa sopir, pete-pete dulu tidak mengenal waktu, soalnya banyak penumpang sepeti karyawan kios atau tempat hiburan malam yang baru pulang kerja. Banyak juga menjelang subuh para penjual yang mau ke pasar untuk berjualan. Informan SDN yang mengaku sempat memiliki 4 unit pete-pete mengungkapkan tentang kondisi penumpang sebelum munculnya moda transportasi online. Menurutnya penumpang dulu sangat menjanjikan, disetiap ruas jalan selalu ada penumpang yang didapatnya.

"Dulu mobil full-full penumpangnya, dalam mobil orang berdesak-desakan apalagi kalau anak sekolah. Setiap kita singgah pasti ada penumpang naik.. lewati satu race juga cepat ji, nda kayak sekarang sepi penumpang terus tambah macet karena banyak sekali taksi online" (Wawancara dengan informan SDN 20 September 2019)

Hal lain yang dikeluhkan oleh para sopir pete-pete adalah jalan saat ini makin macet sehingga race yang bisa mereka jalani juga berkurang, banyaknya taksi online yang aktif beroperasi membuat jalan raya semakin padat. Berkurangnya race dijalani informan sebelumnya dijelaskan di bagian profil informan. Berkurangnya penumpang pete-pete saat ini jelas berimbas langsung ke pendapatan para informan. Dalam sehari, beberapa informan mereka hanya mampu mendapatkan penghasilan bersih sekitar Rp 50 ribu setelah dipotong beli bahan bakar minyak (BBM) dan biaya lain lain. Mereka mengatakan jika pendapatannya saat ini jauh dari lima tahun lalu. Membawa uang pulang Rp 50 ribu 
sampai Rp 70 ribu sekarang ini dianggapnya sudah bagus. Belum lagi jika sopirnya bukan pemilik mobil sendiri.

Dari rangkuman beberapa informan dilapangan, para sopir pete-pete mengaku kecewa dengan kinerja Pemerintah dan Dishub yang dianggap gagal dan lalai dalam menegakkan aturan penyelenggaraan angkutan kepada moda transportasi online. Kuota moda online yang sudah jauh melebihi target sebenarnya melanggar aturan Permenhub yang dikeluarkan terkait kuota yang disetujui. Namun seperti yang telah diungkapkan oleh Hendro dari Dishub Kota Makassar saat diwawancarai terkait jumlah pete-pete saat ini mengaku bahwa masalah moda transportasi online ini levelnya bukan lagi di tingkat daerah, namun di level nasional.

Di sisi lain, baik dari Pemerintah, Dinas Perhubungan, maupun Organda mengakui bahwa moda transportasi online saat ini lebih diminati dibandingkan dengan moda transportasi konvensional (Petepete, Ojek, BIS, Taksi) karena dianggap praktis dan fleksibel. Adanya kepastian baik dari segi tarif, waktu, dan sesuai permintaan (on demand) membuatnya mudah diterima dimasyarakat. Moda transportasi online dianggap menjawab kebutuhan transportasi akan masyarakat yang makin rasional di era internet of things saat ini.

Bagi Weber rasionalitas dilihat sebagai suatu yang tak terelakkan dalam masyarakat modern. rasionalitas adalah roh bagi modernitas. Logika konsumen atau penumpang yang mengedepankan kemudahan dan transportasi yang murah menunjukkan tindakan rasional instrumental di masyarakat. Menurut Weber, Tindakan ini merupakan suatu tindakan sosial yang dilakukan seseorang didasarkan atas pertimbangan dan pilihan sadar (Ritzer, 2001: 126).

Menurut Sztompka (2011: 155) bahwa teknologi dominan memaksakan (menimbulkan) bentuk baru organisasi sosial, kehidupan politik, pola kultur, perilaku sehari-hari dan keyakinan serta sikap. Dengan menganggap teknologi mempunyai logika perkembangannya sendiri yang digerakkan oleh rentetan penemuan dan inovasi, maka cepat atau lambat dampak teknologi modern akan menimbulkan sindrom modernitas menyeluruh, akan menghasilkan kesamaan atau keseragaman yang melanda berbagai masyarakat dan melenyapkan perbedaan lokal.

Sesuai dengan apa yang disebutkan Kasali (2017: 34-35) Disruption adalah sebuah inovasi. Inilah inovasi yang akan menggantikan seluruh sistem lama dengan cara-cara baru. Disruption berpotensi menggantikan pemain-pemain lama dengan yang baru. Disruption menggantikan teknologi lama yang serba fisik dengan teknologi digital yang menghasilkan sesuatu yang benar-benar baru dan lebih efisien, juga lebih bermanfaat. Disruption menggantikan 'pasar lama', industri, dan teknologi, dan menghasilkan suatu kebaruan yang lebih efisien dan menyeluruh. Ia bersifat destruktif dan kreatif.

Bukan hal yang bijak jika masyarakat sepakat untuk menolak inovasi dengan teknologi baru yang 
memudahkan hanya karena inovasi tersebut menganggu keberadaan teknologi yang lama. Pemerintah sebagai regulator tentu perlu mengkaji melalui dinas terkait apa saja yang perlu diatur dalam menyikapi keberadaan inovasi tersebut. Pemerintah juga tidak dapat menafikkan kearifan lokal di setiap kota. Hal yang penting penting perlu dipahami adalah bahwa inovasi yang menganggu merupakan sebuah keniscayaan (Hamid 2017: 13).

\subsection{Strategi Bertahan Hidup Sopir Pete-Pete di Tengah Gempuran Moda Transporatsi Online}

Snel dan Staring dalam Resmi Setia (2005: 6) mengemukakan bahwa strategi bertahan hidup adalah sebagai rangkaian tindakan yang dipilih secara sadar oleh individu dan rumah tangga yang miskin secara sosial ekonomi. Melalui strategi ini sesorang bisa berusaha untuk menambah penghasilan lewat pemanfaatan sumber-sumber lain ataupun mengurangi pengeluaran lewat kuantitas dan kualitas barang dan jasa. Cara-cara individu menyusun strategi dipengaruhi oleh posisi individu atau kelompok dalam struktur masyarakat, sistem kepercayaan dan jaringan sosial yang dipilih, termasuk keahilan dalam memobilitasi sumber daya yang ada, tingkat keterampilan, kepemilikan aset, jenis pekerjaan, status gender dan motivasi pribadi.

Berkurangnya penumpang pete-pete saat ini tentu membuat penghasilan pete-pete kian lama makin menurun. Hal ini dirasakan betul bukan hanya para sopir, namun keluarganya juga. Dalam menyikapi kondisi yang mereka alami, tentu mereka akan melakukan berbagai upaya strategi bertahan hidup demi menjaga keberlangsungan hidupnya. Dalam menjalankan strategi, sopir mungkin tidak hanya menjalankan satu strategi saja. setidaknya ada 3 macam jenis strategi yang bisa mereka jalankan untuk menggali segala potensi dirinya dan keluarga untuk memenuhi kebutuhan rumah tangganya.

\section{Strategi Aktif}

Strategi aktif merupakan strategi bertahan hidup yang dilakukan dengan cara memanfaatkan segala potensi yang dimiliki. Menurut Suharto (2009:31) strategi aktif merupakan strategi yang dilakukan keluarga miskin dengan cara mengoptimalkan segala potensi keluarga (misalnya melakukan aktivitasnya sendiri, memperpanjang jam kerja dan melakukan apapun demi menambah penghasilannya).

Menurut Andrianti (Kusnadi, 2008: 192) salah satu strategi yang digunakan oleh rumah tangga untuk mengatasi kesulitan ekonomi adalah dengan mendorong para istri untuk ikut mencari nafkah.bagi masyarakat tergolong miskin, mencari nafkah bukan hanya menjadi tanggung jawab suami semata tetapi menjadi tanggung jawab semua anggota keluarga sehingga pada keluarga yang tergolong miskin istri juga ikut bekerja demi membantu kebutuhan keluarganya. 
Strategi aktif yang biasanya dilakukan petani kecil adalah dengan diversifikasi penghasilan atau mencari penghasilan tambahan dengan cara melakukan pekerjaan sampingan. Menurut Stamboel (2012: 209) diversifikasi yang dilakukan petani miskin merupakan usaha agar petani dapat keluar dari kemiskinan, diversifikasi yang bisa dilakukan antara lain berdagang, usaha bengkel maupun indutri rumah tangga lainnya.

Dari 18 Sopir Pete-pete yang menjadi Informan, 10 diantaranya yakni Informan DJ, R, SDN, RDN, DN, UD, MR, DR, S, dan DA mengaku sudah tidak lagi narik hingga malam hari. Umumnya mengaku beroperasi dari sekitar jam 07.00 pagi hingga sore atau maghrib pukul 18.00 karena lantaran penumpang sudah sepi dan kebanyakan orang-orang memilih moda transportasi online, belum lagi mereka merasa rugi waktu, tenaga, dan BBM.

Berdasarkan penuturan informan terkait strategi aktif yang dilakukan, dari total 18 informan yang diwawancarai peneliti, sebanyak 10 informan mengaku hanya beroperasi hingga sore hari jam 05.00 dan maghrib 06.30. Mereka merasa upaya memperpanjang jam kerja untuk mendapatkan penghasilan lebih sudah tidak efektif lagi. Hal ini beralasan karena bagi mereka kondisi penumpang saat ini yang menurun drastis dan telah beralih ke moda transportasi online.

Strategi mengoptimalkan segala potensi keluarga dilakukan oleh 3 orang informan atau $20 \%$ dari total informan yakni dengan memanfaatkan anggota keluarganya dimana istri disini turut membantu mencari nafkah. Sedangkan 10 dari total 18 Informan yang diwawancarai mengaku tidak memiliki pekerjaan sampingan dan menjadikan profesi sebagai sopir pete-pete sebagai sumber penghasilan satusatunya.

Ada beberapa strategi aktif yang dilakukan diantaranya memperpanjang jam kerjanya hingga malam hari, ada yang melakukan pekerjaan sampingan seperti (bengkel, kerja tanaman, bersawah), dan ada juga yang memanfaatkan anggota keluarga untuk mencari nafkah seperti berjualan makanan dan minuman.

Di satu sisi yang menjadi concern peneliti dari beberapa penuturan beberapa informan diatas adalah strategi aktif yang bisa dibilang strategi paling progress dan diharap bisa menambah penghasilan atau pendapatan nyatanya tidak bisa dimaksimalkan oleh kebanyakan sopir pete-pete, lantaran bagi mereka tidak efektif dan berpotensi rugi. Contoh ketika mereka harus memperpanjang jam kerja hingga malah hari bukannya mendapat untung, malah mereka merasa rugi biaya, tenaga, dan waktu.

Selain itu banyak informan mengaku hanya mengandalkan profesinya sebagai sopir pete-pete, sama sekali tidak memiliki pekerjaan sampingan. Bila mereka sakit atau tidak narik berarti tidak ada pemasukan hari itu juga. Itu berarti profesi ini sebenarnya renta bila suatu waktu infomran sakit atau mobilnya mengalami kerusakan yang membutuhkan perbaikan dalam waktu yang lama. 


\section{Strategi Pasif}

Strategi pasif merupakan strategi bertahan hidup yang dilakukan dengan cara meminimalisir pengeluaran keluarga sebagaimana pendapat Suharto (2009:31) yang menyatakan strategi pasif adalah strategi bertahan hidup dengan cara mengurangi pengeluaran keluarga (misalnya untuk biaya sandang, pangan, pendidikan, dan sebagainya). Strategi pasif yang biasanya dilakukan oleh petani kecil adalah dengan membiasakan hidup hemat.

Pola hidup hemat yang dilakukan para sopir pete-pete ini sebenarnya hampir sama. Umumnya mereka mengurangi pengeluaran makan seperti jenis lauk yang di beli serta mengurangi pemakaian air dan listrik. Untung-untung bagi mereka bila masih bisa menyisihkan buat biaya sekolah anak dan tabungan. Padahal pola makan sehat dan cukup nutrisi sangat penting bagi keluarga untuk kesehatannya, karena biaya berobat saat ini juga tidak main biayanya.

Strategi pasif yang dilakukan oleh para informan harus dimaklumi karena ini bagian konsekuensi dari penghasilan mereka yang menurun. Makna yang peneliti dapat dari penuturan informan diatas adalah upaya bertahan hidup yang dilakukan saat ini sifatnya hanya sementara. Biaya hidup yang akan naik seiring waktu tapi penghasilan yang stagnan bahkan bisa lebih berkurang membuat peneliti berpikir apakah profesi sopir pete-pete masih bisa bertahan 5 sampai 10 tahun kedepan hanya dengan mengandalkan upaya pasif, sementara kebanyakan informan sopir pete-pete tidak memiliki pekerjaan sampingan.

\section{Strategi Jaringan}

Strategi jaringan adalah strategi yang dilakukan dengan cara memanfaatkan jaringan sosial. Menurut Suharto (2009:31) strategi jaringan merupakan strategi bertahan hidup yang dilakukan dengan cara menjalin relasi, baik formal maupun dengan lingkungan sosialnya dan lingkungan kelembagaan (misalnya meminjam uang kepada tetangga, mengutang di warung atau toko, memanfaatkan program kemiskinan, meminjam uang ke rentenir atau bank dan sebagainya).

Dari penuturan informan terkait strategi jaringan, bisa dilihat ada berbagai macam strategi bertahan yang ditempuh untuk memenuhi kebutuhan hidupnya. Diantaranya beberapa informan mengaku meminjam uang (baik ke tetangga, rekan kerja maupun di bank), memanfaatkan relasi sosial sehingga sering mendapatkan tawaran kerja dari lingkungan sekitar tempatnya mencari nafkah, menjalin relasi kerja dengan perusahan swasta, ada yang memanfaatkan program bantuan pemerintah, dan ada juga yang ikut program kerja pemerintah.

Perihal meminjam uang untuk memenuhi kebutuhan hidup, kebanyakan informan mengaku enggan lantaran takut tidak bisa membayarnya. Alasannya seragam karena kondisi pendapatan yang tidak 
sebagus dulu. Menurut mereka meminjam uang saat ini hanya akan menambah beban dan penderitaan baru.

Strategi jaringan yang ditempuh para informan ada yang sifatnya sementara, ada juga sifatnya berkepanjangan. Artinya hal-hal yang berkaitan dengan relasi sosial atau kerja, bisa dibilang berkepanjangan, manfaatnya dirasa dalam waktu yang relatif lama. Sedangkan seperti meminjam uang bisa dikata sifatnya hanya sementara karena sifatnya konsumtif tidak produktif terutama bagi mereka yang memiliki penghasilan terbatas.

\section{KESIMPULAN}

Pesatnya teknologi dan informasi merubah logika konsumsi di masyarakat. Bila konsumen dulu cukup dengan transportasi yang murah dan mudah. Di era "internet of things" saat ini, logika dan tindakan konsumen semakin rasional. Orang-orang lebih memlilih moda transportasi on demand yang dianggap tidak hanya murah dan mudah, tapi juga nyaman serta dapat di akses kapan dan dimana saja. Para pengambil kebijakan pun berasumsi bahwa regulasi yang dibuat harus menyesuaikan dengan kebutuhan masyarakat banyak saat ini.

Eksistensi pete-pete yang menurun drastis secara signifikan beberapa tahun terakhir ini bukan tanpa sebab. Beralihnya penumpang pete-pete ke moda transportasi online membuat keberadaan pete-pete berada di ambang batas kritis saat ini. Beberapa pete-pete bahkan sudah tidak tercatat di Dinas Perhubungan karena tidak melakukan registrasi (KIR, izin trayek, dll) namun tetap nekat beroperasi. Hal tersebut terjadi lantaran penghasilan sopir pete-pete yang hanya cukup untuk biaya rumah tangganya.

Strategi bertahan hidup yang ditempuh oleh para informan sopir pete-pete juga tidak bisa dimaksimalkan akibat beberapa kondisi tertentu. Kebanyakan sopir juga hanya mengandalkan penghasilan dari narik pete-pete. Strategi-strategi yang dijalani juga sifatnya sementara bisa dibilang hanya memperlambat proses pete-pete menuju kondisi paling kritisnya.

Bila melihat beberapa dekade kebelakang, pete-pete juga sejatinya sebuah inovasi yang mengganggu bagi moda transportasi tradisonal seperti Becak dan Delman. Namun karena kemajuan teknologi dan munculnya banyak inovasi terbaru, kini giliran pete-pete yang terganggu dengan kehadiran moda transportasi yang lebih inovatif dan efisien. Pete-pete bisa dibilang kalah dalam hasrat dan logika pertumbuhan saat ini. Bila pete-pete tidak dilakukan inovasi dan pembaruan, maka tidak menutup kemungkinan salah satu entitas kota daeng ini tinggal kenangan.

\section{DAFTAR PUSTAKA}

Asri, Syamsul. 2015. Pete-pete dan Sejarahnya (Atau Tentang Politik Ingatan di Kota Makassar. 
Makassar: Jurnal Universitas Fajar Makassar: 89

Hamid, Edy Suandi. 2017. Distruptive Innovation: Manfaat dan Kekurangan Dalam Konteks Pembangunan Ekonomi. Jurnal Universitas Islam Indonesia. Yogyakarta (hal 1-20)

Kasali, Rhenald. 2017. DISRUPTION. Jakarta: PT Gramedia Pustaka Utama.

Kasali, Rhenald. 2017. TOMORROW IS TODAY: Series On Disruption. Jakarta: Mizan Anggota IKAPI.

Kusnadi. 2008. Akar Kemiskinan Nelayan. Yogyakarta. LkiS Yogyakarta

Maleong, Lexy. J. 2016. Metodologi Peneltian Kualitatif. Edisi: Revisi. Bandung: PT Remaja Rosdakarya.

Mulyana \& Dedi Junaedi. 2008. METODOLOGI ILMU KUALITATIF: Paradigma $\quad$ Baru $\quad$ Ilmu Komunikasi dan Ilmu Sosial Lainnya. Bandung: PT. Remaja Rosdakarya.

Narbuko, Cholid \& Abu Ahmadi. 2007. Metodologi Penelitian. Jakarta: PT. Bumi Aksara.

Noor, Juliansyah. 2011. Metode Penelitian: Skripsi, Tesis, Disertasi,dan Karya Ilmiah. Jakarta: Kencana.

Poerwandari, E.K. 1998. Pendekatan Kualitatif Dalam Penelitian Psikologi. Jakarta: Lembaga Pengembangan Sarana Pengukuran dan Pendidikan Psikologi (LPSP3) Fakultas Psikologi Universitas Indonesia

Putra, Adris Ade. 2017. Analisis Keseimbangan Jumlah Armada Angkutan Umum Berdasarkan Kebutuhan Penumpang. Kendari. Jurnal Ilmu dan Terapan Bidang Teknik Sipil Universitas Haluleo. P.3.

Resmi Setia. 2005. Gali Tutup Lubang itu Biasa : Strategi Buruh Menanggulangi Persoalan Dari Waktu Ke Waktu. Bandung: Yayasan Akatiga.

Ritzer, George. 2001. Sosiologi Ilmu Berparadigma Ganda. Jakarta: PT Rajawali Pers

Soeharto, Edi. 2009. Membangun Masyarakat Memberdayakan Masyarakat. Bandung: PT Refika Aditama

Stamboel, Kemal. 2012. Panggilan Keberpihakan, Strategi Mengakhiri Kemiskinan di Indonesia. Jakarta: Gramedia Pustaka Utama

Sugiyono, 2009. Metode Penelitian, Kuantitatif, Kualitatif, dan R\&D. Bandung: Alfabeta.

Sugiyono, 2015. Metode Penelitian Kombinasi (Mix Methods). Bandung: Alfabeta.

Sztompka, Piotr. 2011. SOSIOLOGI PERUBAHAN SOSIAL. Jakarta: Prenada.

\section{Sumber lain:}

Lucky R. (2017, 10 Maret). Rentetan Gesekan Sopir Angkutan Konvensional vs Angkutan Online. (diakses 1 November 2018) https://m.kumparan.com/@kumparannews/daftar-pertikaiantransportasi-online-vs-transportasi-konvensional (diakses 1 November 2018)

Wahyu Susanto S. (2017, 28 September). Sopir Pete-pete dan Tukang Bentor Razia Ojek Online di Makassar.

https://www.google.com/amp/news.rakyatku.com/amp/67296https://www.google.com/amp/news .rakyatku.com/amp/67296 (diakses 1 November 2018) 